Article

\title{
Reassessment of Dyfrolomyces and Four New Species of Melomastia from Olive (Olea europaea) in Sichuan Province, China
}

\author{
Wen-Li Li ${ }^{1}$, Sajeewa S. N. Maharachchikumbura ${ }^{1}\left(\mathbb{D}\right.$, Ratchadawan Cheewangkoon $^{2}$ and Jian-Kui Liu ${ }^{1,2, *(D)}$ \\ 1 Center for Informational Biology, School of Life Science and Technology, University of Electronic Science and \\ Technology of China, Chengdu 611731, China; wendy316@tom.com (W.-L.L.); \\ sajeewa83@yahoo.com (S.S.N.M.) \\ 2 Department of Entomology and Plant Pathology, Faculty of Agriculture, Chiang Mai University, \\ Chiang Mai 50200, Thailand; ratchadawan.c@cmu.ac.th \\ * Correspondence: liujiankui@uestc.edu.cn; Tel.: +86-028-6183-1832
}

check for updates

Citation: Li, W.-L.;

Maharachchikumbura, S.S.N.;

Cheewangkoon, R.; Liu, J.-K

Reassessment of Dyfrolomyces and

Four New Species of Melomastia from Olive (Olea europaea) in Sichuan

Province, China. J. Fungi 2022, 8, 76. https://doi.org/10.3390/jof8010076

Academic Editor: Jose Cano

Received: 6 December 2021

Accepted: 10 January 2022

Published: 13 January 2022

Publisher's Note: MDPI stays neutral with regard to jurisdictional claims in published maps and institutional affiliations.

Copyright: (C) 2022 by the authors. Licensee MDPI, Basel, Switzerland. This article is an open access article distributed under the terms and conditions of the Creative Commons Attribution (CC BY) license (https:// creativecommons.org/licenses/by/ $4.0 /)$.

\begin{abstract}
Pleurotremataceae species are saprobes on decaying wood in terrestrial, mangrove, and freshwater habitats. The generic boundary of the family has traditionally been based on morphology. All genera of Pleurotremataceae have a high degree of morphological overlap, of which the generic circumscription of Melomastia and Dyfrolomyces has not been well resolved. Thus, the delimitation of genera has always been challenging. Melomastia traditionally differs from Dyfrolomyces in having 2-septate, oblong, with obtuse-ends ascospores. These main characteristics have been used to distinguish Melomastia from Dyfrolomyces for a long time. However, the above characteristics sometimes overlap among Dyfrolomyces and Melomastia species. Based on the morphology and multigene phylogeny with newly obtained data, we synonymized Dyfrolomyces under Melomastia following up-to-date results. Four novel species (i.e., Melomastia fusispora, M. oleae, M. sichuanensis and M. winteri) collected from the dead branches of Olea europaea L. in Chengdu Olive Base, Sichuan Province in China are introduced based on detailed morphological characterization and phylogenetic analyses of sequences based on nuclear ribosomal (LSU and SSU) and protein-coding gene (tef1- $\alpha$ ). The 11 new combinations proposed are Melomastia aquatica (=Dyfrolomyces aquaticus), M. chromolaenae (=D. chromolaenae), $M$. distoseptata (=D. distoseptatus), M. mangrovei (=D. mangrovei), M. marinospora (=D. marinosporus), $M$. neothailandica (=D. neothailandicus), M. phetchaburiensis (=D. phetchaburiensis), M. sinensis (=D. sinensis), M. thailandica ( $=D$. thailandica), M. thamplaensis $(=D$. thamplaensis) and M. tiomanensis $(=D$. tiomanensis).
\end{abstract}

Keywords: 15 new taxa; Dothideomycetes; morphology; multigene; phylogeny

\section{Introduction}

The family Pleurotremataceae was introduced by Watson [1] for the monotypic genus Pleurotrema Müll. Arg. with P. polysemum as the type of species. The family is characterized by a clypeus on the substrate, immersed ascomata and multi-septate ascospores, with or without a sheath in bitunicate/fissitunicate asci [1,2]. Barr assigned Pleurotremataceae to Xylariales and accepted five genera, viz. Daruvedia Dennis., Melomastia Nitschke ex Sacc., Phomatospora Sacc., Pleurotrema Müll. Arg. and Saccardoella Speg., based on their unitunicate and non-fissitunicate ascal characteristics [2]. Later, Daruvedia and Phomatospora were transferred to Pleosporales and Phomatosporales based on DNA sequence data, respectively [3,4]. Melomastia and Saccardoella were referred to Ascomycota genera incertae sedis $[5,6]$, while Pleurotrema was retained in Pyrenulales [7]. The familial placement of Pleurotrema has been controversial due to the confusion over the nature of the asci, as they are neither typically unitunicate nor bitunicate [8,9]. Thus, Pleurotrema has been classified in the Xylariales [10], Pyrenulales [11] and Chaetosphaeriales [12]. The type of species P. polysemum was re-examined to confirm the placement of Pleurotrema $[2,13]$. The bitunicate, 
non-fissitunicate and not lichenized asci of Pleurotrema determined that it has morphological affinities to the genera Melomastia and Saccardoella. Based on the above evidence, Maharachchikumbura et al. [13] excluded Pleurotremataceae from Sordariomycetes and placed it in Dothideomycetes.

Currently, three genera: Dyfrolomyces K. D. Hyde, Melomastia Nitschke ex Sacc and Pleurotrema are accepted in Pleurotremataceae [14,15]. The genus Melomastia was introduced by Saccardo [16] to accommodate M. mastoidea (=Melomastia friesii Nitschke) and is characterized by globose ascomata with erumpent apex, cylindrical asci and 2-septate, ovoid ascospores with or without a gelatinous sheath [2,17]. As the placement of the type species of Melomastia within Ascomycota remained unresolved and was based solely on morphological observations, this genus was classified under Ascomycota genera incertae sedis [13]. Norphanphoun et al. [18] introduced Melomastia italica with sequence data and assigned Melomastia in Pleurotremataceae, while Dyfrolomyces maolanensis was synonymized under $M$. maolanensis based on phylogeny and morphological characteristics. Subsequently, two species from Clematis sp., M. clematidis and M. fulvicoma were introduced by Phukhamsakda et al. [19]. Currently, 44 epithets of Melomastia are listed in Index Fungorum (http:/ / www.indexfungorum.org/Names/Names.asp, accessed on 1 December 2021), though most of them lack sequence data.

Pang et al. [20] established the family Dyfrolomycetaceae with the type of genus Dyfrolomyces to accommodate $D$. tiomanensis and accept three marine species transferred from Saccardoella (i.e., Saccardoella mangrovei, S. marinospora and S. rhizophorae). Subsequently, Dyfrolomycetaceae was raised as the order Dyfrolomycetales [21]. Maharachchikumbura et al. [13] synonymized Dyfrolomycetaceae under Pleurotremataceae based on morphological investigations. Dyfrolomyces is charactered by immersed, clypeate, globose ascomata, 8-spored, bitunicate, fissitunicate, cylindrical asci with relatively short pedicel, and overlapping uniseriate, fusiform, hyaline, multi-septate ascospore with or without a gelatinous sheath, which is very similar to Melomastia. However, the affiliation between these two genera is unclear due to the lack of sequence data of Melomastia species. With the description of Melomastia italica, Melomastia was revealed as closely related to Dyfrolomyces, and there was no significant support in the molecular phylogenies to differentiate Melomastia from Dyfrolomyces [18]. Presently, 11 Dyfrolomyces species have been accepted in the genus.

During a survey of micro-fungi on olive in Sichuan Province, China, we collected nine pleurotrema-like taxa from Olea europaea. Four new species, viz. Melomastia fusispora, $M$. oleae, $M$. sichuanensis and $M$. winteri were introduced. Moreover, we evaluated the morphology and phylogeny of accepted species in Dyfrolomyces and Melomastia, and synonymized Dyfrolomyces under Melomastia.

\section{Materials \& Methods}

\subsection{Isolation and Morphology}

The dead branches of Olea europaea were collected from Chengdu Olive Base, Shuangliu District, Chengdu City, Sichuan Province, China, in 2020. The samples were transported to a laboratory in paper envelopes. Examination and observation of samples were carried out as detailed by Senanayake et al. [22]. Measurements were made with the Tarosoft (R) Image Framework program v. 0.9.7, following Liu et al. [23].

Single spore isolations were prepared following the method of Chomnunti et al. [24]. Germinating spores were transferred aseptically onto fresh potato dextrose agar (PDA) plates and incubated at room temperature in daylight. The strains isolated in this study were deposited at the China General Microbiological Culture Collection Center (CGMCC), Beijing, China and the University of Electronic Science and Technology Culture Collection (UESTCC), Chengdu, China. Herbarium specimens were deposited at Herbarium of Cryptogams, Kunming Institute of Botany Academia Sinica (KUN-HKAS), Kunming, China and Herbarium, University of Electronic Science and Technology (HUEST), Chengdu, China. 


\subsection{DNA Extraction, PCR Amplification and Sequencing}

Genomic DNA was extracted from $14 \mathrm{~d}$-old fungal colonies growing on PDA at $25^{\circ} \mathrm{C}$ using the EZ geneTM fungal gDNA kit (GD2416) according to the manufacturer's instructions. Phylogenetic analyses were conducted using partial sequences of the large subunit rDNA (28S, LSU), small subunit rDNA (18S, SSU) and the translation elongation factor-1 alpha (tef1- $\alpha$ ) using the primer pairs LR0R/LR5 [25], NS1/NS4 [26] and 983F/2218R [27], respectively. Polymerase chain reaction (PCR) amplifications were conducted in $25 \mu \mathrm{L}$ reaction volumes. The PCR mixture consisted of $2 \times$ PCR MasterMix $(12.5 \mu \mathrm{L})$ (Tsingke Co., China), genomic DNA $(1 \mu \mathrm{L})$, each primer $(1 \mu \mathrm{L})$ and ddH2O $(9.5 \mu \mathrm{L})$. The PCR thermal cycle program for LSU, SSU and tef1- $\alpha$ amplification was performed using the following parameters: $94{ }^{\circ} \mathrm{C}$ for $3 \mathrm{~min}$, followed by 35 cycles of denaturation at $94{ }^{\circ} \mathrm{C}$ for $30 \mathrm{~s}$, annealing at $56{ }^{\circ} \mathrm{C}$ for $50 \mathrm{~s}$, elongation at $72{ }^{\circ} \mathrm{C}$ for $1 \mathrm{~min}$ and a final extension at $72{ }^{\circ} \mathrm{C}$ for $10 \mathrm{~min}$, and finally kept at $4{ }^{\circ} \mathrm{C}$ in a thermal cycle. PCR amplification products were visualized on $1 \%$ agarose electrophoresis gels stained with GoldView. Purification and sequencing of PCR products were carried out at Beijing Tsingke Biological Engineering Technology and Services Co., Ltd. (Beijing, China).

\subsection{Phylogenetic Analysis}

Related sequences were downloaded from GenBank based on BLAST searches and previous publications $[15,19,28,29]$ (Table 1). Two species of Anisomeridium were selected as the outgroup taxa. Consensus sequences were assembled with BioEdit v. 7.2.3 [30], aligned using MAFFT v. 7.110 online programs (http:/ / mafft.cbrc.jp/alignment/server/, accessed on 16 August 2021) [31] and manually edited via BioEdit v. 7.2.3 [30].

The evolutionary model of nucleotide substitution was selected independently for each locus using MrModeltest 2.2 [32]. GTR + G + I substitution model was selected for LSU, SSU and tef1- $\alpha$ partitions. The analyses of maximum likelihood (ML), maximum parsimony (MP) and Bayesian inference (BI) were carried out as detailed in Dissanayake et al. [33]. The programs used were raxmlGUI v. 1.3 [34] for ML, PAUP v.4.0b10 [35] for MP and MrBayes v3.1.2 [36] for BI. The alignment generated in this study was submitted to TreeBASE (https://treebase.org/treebase-web/home.html, accessed on 30 November 2021) with a submission number: ID29068. Taxonomic novelties were submitted to the Faces of Fungi database (https:/ / www.facesoffungi.org/, accessed on 25 November 2021) [37] and MycoBank (https:/ / www.mycobank.org/, accessed on 25 November 2021) [38]. Trees were visualized with FigTree v. 1.4.2 [39], and the layout was edited using Adobe Illustrator CS6.

Table 1. Taxa used in the phylogenetic analyses and their GenBank accession numbers.

\begin{tabular}{|c|c|c|c|c|c|}
\hline \multirow{2}{*}{ Taxa } & \multirow{2}{*}{ Strain Numbers } & \multicolumn{3}{|c|}{ GenBank Accession Numbers } & \multirow{2}{*}{ References } \\
\hline & & LSU & SSU & tef1- $\alpha$ & \\
\hline $\begin{array}{l}\text { Acrospermum } \\
\text { adeanum }\end{array}$ & M 133 & EU940104 & EU940031 & $\mathrm{N} / \mathrm{A}$ & [40] \\
\hline A. compressum & M 151 & EU940084 & EU940012 & $\mathrm{N} / \mathrm{A}$ & [40] \\
\hline A. graminum & M 152 & EU940085 & EU940013 & $\mathrm{N} / \mathrm{A}$ & [40] \\
\hline $\begin{array}{l}\text { Anisomeridium } \\
\text { phaeospermum }\end{array}$ & MPN539 & JN887394 & JN887374 & JN887418 & [41] \\
\hline A. ubianum & MPN94 & $\mathrm{N} / \mathrm{A}$ & JN887379 & JN887421 & {$[41]$} \\
\hline $\begin{array}{c}\text { Melomastia } \\
\text { chromolaenae }\end{array}$ & MFLUCC 17-1434 * & KY111905 & MT214413 & MT235800 & [42] \\
\hline M. clematidis & MFLUCC 17-2092 * & MT214607 & MT226718 & MT394663 & [19] \\
\hline M. distoseptata & NFCCI: $4377^{*}$ & MH971236 & $\mathrm{N} / \mathrm{A}$ & $\mathrm{N} / \mathrm{A}$ & {$[15]$} \\
\hline M. fulvicomae & MFLUCC 17-2083 * & MT214608 & MT226719 & $\mathrm{N} / \mathrm{A}$ & [19] \\
\hline
\end{tabular}


Table 1. Cont.

\begin{tabular}{|c|c|c|c|c|c|}
\hline \multirow{2}{*}{ Taxa } & \multirow{2}{*}{ Strain Numbers } & \multicolumn{3}{|c|}{ GenBank Accession Numbers } & \multirow{2}{*}{ References } \\
\hline & & LSU & SSU & tef1- $\alpha$ & \\
\hline M. fusispora & CGMCC $3.20618 *$ & OK623464 & OK623494 & OL335189 & This study \\
\hline M. fusispora & UESTCC 21.0001 & OK623465 & OK623495 & OL335190 & This study \\
\hline M. italica & MFLUCC 15-0160* & MG029458 & MG029459 & $\mathrm{N} / \mathrm{A}$ & [18] \\
\hline M. maolanensis & GZCC 16-0102* & KY111905 & KY111906 & KY814762 & [28] \\
\hline M. neothailandica & MFLU 17-2589* & NG068294 & $\mathrm{N} / \mathrm{A}$ & $\mathrm{N} / \mathrm{A}$ & [43] \\
\hline M. oleae & CGMCC $3.20619 *$ & OK623466 & OK623496 & OL335191 & This study \\
\hline M. oleae & UESTCC 21.0003 & OK623467 & OK623497 & OL335192 & This study \\
\hline M. oleae & UESTCC 21.0005 & OK623468 & OK623498 & OL335193 & This study \\
\hline M. oleae & UESTCC 21.0006 & N/A & OK623499 & OL335194 & This study \\
\hline M. phetchaburiensis & MFLUCC 15-0951* & MF615402 & MF615403 & $\mathrm{N} / \mathrm{A}$ & [44] \\
\hline M. rhizophorae & ВСС 15481 & $\mathrm{~N} / \mathrm{A}$ & KF160009 & $\mathrm{N} / \mathrm{A}$ & {$[20]$} \\
\hline M. rhizophorae & JK 5439 A & GU479799 & GU479766 & GU479860 & [20] \\
\hline M. sichuanensis & CGMCC $3.20620 *$ & OK623469 & OK623500 & OL335195 & This study \\
\hline M. sichuanensis & UESTCC 21.0008 & OK623470 & OK623501 & OL335196 & This study \\
\hline M. sinensis & MFLUCC 17-1344* & MG836699 & MG836700 & $\mathrm{N} / \mathrm{A}$ & [45] \\
\hline M. thailandica & MFLUCC 15-0945* & KX611366 & KX611367 & $\mathrm{N} / \mathrm{A}$ & [46] \\
\hline M. thamplaensis & MFLUCC 15-0635* & KX925435 & KX925436 & KY814763 & [28] \\
\hline M. tiomanensis & MFLUCC 13-0440 * & KC692156 & KC692155 & KC692157 & [20] \\
\hline M. winteri & CGMCC 3.20621 * & OK623471 & OK623502 & OL335197 & This study \\
\hline $\begin{array}{c}\text { Muyocopron } \\
\text { castanopsis }\end{array}$ & MFLUCC 14-1108* & KU726965 & KU726968 & MT136753 & [47] \\
\hline M. dipterocarpi & MFLU 17-2608 & KU726966 & KU726969 & MT136754 & [47] \\
\hline M. garethjonesii & MFLUCC 16-2664 * & KY070274 & KY070275 & $\mathrm{N} / \mathrm{A}$ & [48] \\
\hline M. heveae & MFLUCC 17-0066* & MH986832 & MH986828 & $\mathrm{N} / \mathrm{A}$ & [29] \\
\hline M. lithocarpi & MFLUCC 14-1106* & KU726967 & KU726970 & MT136755 & [47] \\
\hline $\begin{array}{l}\text { Palawania } \\
\text { thailandensis }\end{array}$ & MFLICC 14-1121 * & KY086494 & $\mathrm{N} / \mathrm{A}$ & $\mathrm{N} / \mathrm{A}$ & [49] \\
\hline P. thailandensis & MFLU 16-1873 & KY086493 & KY086495 & $\mathrm{N} / \mathrm{A}$ & [49] \\
\hline $\begin{array}{l}\text { Stigmatodiscus } \\
\text { enigmaticus }\end{array}$ & CBS $132036^{*}$ & KU234108 & KU234130 & $\mathrm{N} / \mathrm{A}$ & [50] \\
\hline S. labiatus & CBS $144700 *$ & MH756065 & MH756065 & MH756083 & [51] \\
\hline S. oculatus & CBS 144701 * & MH756069 & $\mathrm{N} / \mathrm{A}$ & MH756086 & [51] \\
\hline S. pruni & CBS $142598 *$ & KX611110 & KX611110 & KX611111 & [52] \\
\hline $\begin{array}{c}\text { Superstratomyces } \\
\text { albomucosus }\end{array}$ & CBS $140270 *$ & KX950439 & KX950467 & KX950471 & [53] \\
\hline S. atroviridis & CBS $140272 *$ & NG058271 & NG063075 & LR812724 & [53] \\
\hline S. flavomucosus & CBS $353.84 *$ & KX950438 & KX950462 & KX950470 & [53] \\
\hline
\end{tabular}

Type strains are indicated with *; newly generated sequences in this study are indicated in bold. "N/A" denotes sequences that are not available. Abbreviations: BCC: BIOTEC Culture Collection, Bangkok, Thailand; CBS: CBS-KNAW Collections, Westerdijk Fungal Biodiversity Institute, Utrecht, The Netherlands; CGMCC: China General Microbiological Culture Collection Center; MFLU: Mae Fah Luang University Herbarium Collection; MFLUCC: Mae Fah Luang University Culture Collection, Chiang Rai, Thailand; MPN: Matthew P. Nelsen; NFCCI: National Fungal Culture Collection of India, India; GZCC: Guizhou culture collection, Guizhou, China; JK: J. Kohlmeyer; UESTCC: University of Electronic Science and Technology Culture Collection. 


\section{Results}

\subsection{Phylogenetic Analyses}

The aligned sequence matrix comprises LSU, SSU, and tef1- $\alpha$ sequence data of 42 taxa representing four orders (Acrospermales, Muyocopronales, Stigmatodiscales and Superstratomycetales) and two families (Palawaniaceae and Pleurotremataceae), with Anisomeridium phaeospermum (MPN539) and A. ubianum (MPN94) as outgroup taxa. The aligned dataset comprised 2899 characters, including gaps (LSU: 1-894; SSU: 895-1942; tef1- $\alpha$ : 1943-2899). The best scoring RAxML tree is shown in Figure 1. The analyzed ML, MP and Bayesian trees were similar in topology and did not conflict significantly. Pleurotremataceae was resolved as a monophyletic clade. Nine strains obtained in this study were grouped in Pleurotremataceae and represented four new species viz. Melomastia fusispora, M. oleae, M. sichuanensis and M. winteri. Two isolates of Melomastia sichuanensis (CGMCC3.20620, UESTCC 21.0008) are sisters to M. clematidis (MFLUCC 17-2092) with high statistical support (92\% ML BS/86\% MP BS/ 1.0 PP). Four isolates of Melomastia oleae (UESTCC 21.0006, UESTCC 21.0005, CGMCC3.20619, UESTCC 21.0003) formed a distinct clade sister to the clade containing M. fusispora (CGMCC3.20618, UESTCC 21.0001), M. winteri (CGMCC3.20621) and M. thamplaensis (MFLUCC 15-0635) with strong statistical support (100\% ML BS/100\% MP BS/ 1.0 PP). The two isolates of Melomastia fusispora (CGMCC3.20618, UESTCC 21.0001) clustered with M. winteri (CGMCC3.20621) with high statistical support (97\% ML BS/100\% MP $\mathrm{BS} / 1.0 \mathrm{PP})$.

\subsection{Taxonomy}

\subsubsection{Melomastia}

Melomastia Nitschke ex Sacc., Atti Soc. Veneto-Trent. Sci. Nat., Padova, Sér. 44: 90 (1875), emend.

MycoBank: MB 3118.

=Dyfrolomyces K.D. Hyde, K.L. Pang, Alias, Suetrong \& E.B.G. Jones, Cryptogamie, Mycologie, 34 (1): 223-232 (2013).

Saprobic on woody branches, twigs and culms in terrestrial, freshwater, and mangrove habitats. Sexual morph: appearing as raised, dome-shaped, black dots on host surface. Ascomata: perithecial, scattered, solitary, immersed, erumpent or rarely superficial, globose, subglobose or ellipsoidal, coriaceous to carbonaceous, dark brown, clypeate, papillate ostiole. Papilla: narrow, conical, periphysate, often umbilicate. Periphyses: hyaline, filamentous. Peridium: one-layered or two-layered, with an outer layer composed of host cells, interdispersed with fungi hyphae, forming a textura intricata and inner layer of thick-walled cells of textura angularis. Hamathecium: comprising numerous, filamentous, flexuose, septate pseudoparaphyses embedded in a gelatinous matrix. Asci: 8-spored, bitunicate, fissitunicate, cylindrical, with a relatively short pedicel, apically rounded or flattened with a distinct ocular chamber and ring-like subapical apparatus. Ascospores: overlapping uni-seriate, hyaline, ellipsoid to fusiform, rarely curved, 1-10-septate, not or slightly constricted at the septum, with or without a mucilaginous sheath. Asexual morph: unknown.

Type species: Melomastia mastoidea (Fr.) J. Schröt., in Cohn, Krypt.-Fl. Schlesien (Breslau) 3.2(3): 320 (1894).

MycoBank: 205357.

三Sphaeria lonicerae Sowerby, Col. Engl. Fung. Mushr. (London) 3(no. 27) (1803).

=Sphaeria mastoidea Fr., K. svenska Vetensk-Akad. Handl., Ser. 338: 267 (1817).

=Sphaeria revelata Berk. \& Broome, Ann. Mag. nat. Hist., Ser. 29: 325 (1852).

=Sphaeria fraxinicola Curr., Trans. Linn. Soc. London 22: 333 (1859).

=Melomastia friesii Nitschke, in Fuckel, Jb. nassau. Ver. Naturk. 25-26: 306 (1871).

=Conisphaeria mastoidea (Fr.) Stev., (1879).

=Psilosphaeria lonicerae (Sowerby) Stev., Mycol. Scot.: 388 (1879).

=Phyllosticta fraxinicola Sacc., Syll. fung. (Abellini) 3: 12 (1884).

=Trematosphaeria mastoidea (Fr.) G. Winter, Rabenh. Krypt.-Fl., Edn 2 (Leipzig) 1.2: 274 (1885).

=Conisphaeria friesii (Nitschke) Cooke, Grevillea 16 (no. 79 ): 87 (1888). 
=Hypoxylon mastoideum (Fr.) P.M.D. Martin, Jl S. Afr. Bot. 34: 176 (1968).

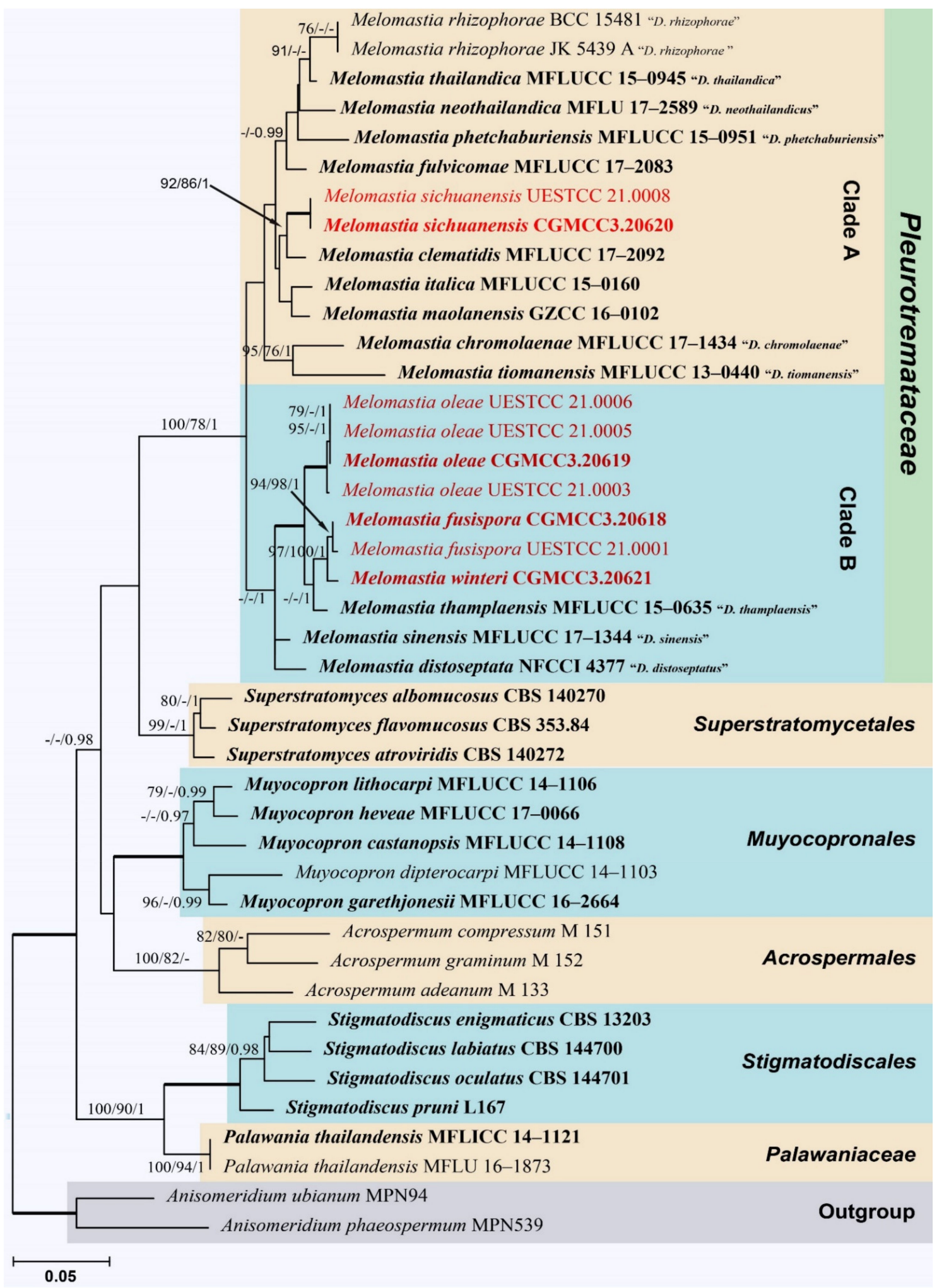

Figure 1. Phylogram generated from maximum likelihood (ML) based on an LSU-SSU-tef1- $\alpha$ sequence matrix. The tree is rooted with Anisomeridium phaeospermum (MPN539) and A. ubianum (MPN94). The ML, MP bootstrap supports ( $\geq 75 \%$ ) and BI posterior probabilities ( $\geq 0.95 \mathrm{PP})$ supports are given near the nodes, respectively. Branches with 100\% ML BS, 100\% MP BS and 1.00 PP are thickened. Ex-type strains are in bold, and the newly introduced taxa are in red. 
Notes: Melomastia was introduced by Nitschke [16] with $M$. friesii as the type species found on Viburnum opulus L. (Adoxaceae) in Germany. Later, the species was synonymized under Melomastia mastoidea [54] and is recognized by its immersed, obpyriform ascomata with a conical papillate ostiole, peridium of several layers of brown to dark brown, compressed cells, unitunicate asci and 2-septate, oblong, obtuse ends and hyaline ascospores [2]. Chen et al. [55] checked the paratype of Melomastia mastoidea isolated from Taiwan and noted its ascomatal peridium composed of a 2-zone. Among currently known Melomastia species, $M$. clematidis, $M$. fulvicomae and M. maolanensis also possesses a 2-zone ascomatal peridium, while $M$. italica possesses 1-zone. Melomastia mastoidea is saprobic on a wide range of woody and semi-woody substrata, including stems and twigs of Epilobium, Eupatorium, Hedera, Lonicera, Symphoricarpus and Uimus [2].

Pang et al. [20] introduced Dyfrolomyces to accommodate species with immersed coriaceous ascomata with clypeated ostiolar neck, peridium composed of 2-zone, multicellular ascospores. The family Dyfrolomycetaceae was proposed based on the phylogenetic analyses of a multi-gene [20] to accommodate this single genus. Morphologically similar Melomastia species were not included in their analyses due to the limited availability of the sequence data, and thus the affiliation of these two genera has remained unclear.

The presence of multi-septate ascospores in "Dyfrolomyces" is key in differentiating "Dyfrolomyces" from Melomastia species. However, some Melomastia species, such as M. maolanensis has 3-septate ascospores, which are morphologically similar to "Dyfrolomyces" but were phylogenetically related to Melomastia in previous studies $[15,18,20]$. Thus, the ascospore septation is not a specific character for the generic delimitation of these two genera. In the present study, phylogenetic analyses of combined LSU, SSU and tef1- $\alpha$ sequence data showed taxa of Pleurotremataceae were separated into two major clades with well-supported bootstrap values (100\% ML BS/78\% MP BS/1.00 BI, Figure 1). The clade A consisted of Melomastia rhizophorae ("Dyfrolomyces rhizophorae"), M. thailandica ("D. thailandica"), M. neothailandica ("D. neothailandicus"), M. phetchaburiensis ("D. phetchaburiensis"), M. fulvicomae, M. sichuanensis, M. clematidis, M. italica, M. chromolaenae ("D. chromolaenae") and M. tiomanensis ("D. tiomanensis"), while the clade B consisted of M. oleae, M. fusispora, M. winteri, M. thamplaensis ("D. thamplaensis"), M. sinensis ("D. sinensis") and M. distoseptata ("D. distoseptatus"). However, the taxa in these two clades have no noticeable morphological differences. We conclude the Melomastia and "Dyfrolomyces" are congeneric based on molecular phylogeny and morphology. Further studies with fresh collections are needed to resolve the taxonomic relationships in Pleurotremataceae and its sexual-asexual connections.

Melomastia fusispora W.L. Li, Maharachch. \& Jian K. Liu, sp. nov. Figure 2.

MycoBank number: MB 841499; Facesoffungi number: FoF10533.

Etymology: Refers to the shape of the ascospore.

Holotype: HKAS 121316.

Saprobic on dead branches of Olea europaea. Sexual morph: Ascomata, visible as numerous, black, cone-shaped structures on the host surface, solitary, gregarious, immersed to erumpent through host tissue, pyriform, coriaceous to carbonaceous, dark brown to black, rough-walled, ostiolate, $432-624 \times 527-618 \mu \mathrm{m}$ diam. $(\bar{x}=528 \times 572 \mu \mathrm{m}$, $\mathrm{n}=15)$. Ostioles central, carbonaceous, dark brown to black, papillate, periphyses filling the ostiolar canal 19.14-343.5 $\times 65.8-283.5 \mu \mathrm{m}(\bar{x}=174.5 \times 181 \mu \mathrm{m}, \mathrm{n}=15)$. Peridium two-layered, an outer layer of cells of textura intricata composed of host cells interspersed with fungal hyphae and an inner layer of thick-walled cells of textura angularis, 25.5-61.5 $\mu \mathrm{m}(\bar{x}=41 \mu \mathrm{m}, \mathrm{n}=15)$ wide. Hamathecium comprises numerous, dense, filiform, unbranched, hyaline, aseptate pseudoparaphyses, 2-2.6 $\mu \mathrm{m}(\bar{x}=2.3 \mu \mathrm{m}, \mathrm{n}=30)$ wide. Asci 8-spored, bitunicate, cylindrical, slightly flexuous, apically round, with well-developed ocular chamber, $200-231 \times 7.6-9.2 \mu \mathrm{m}(\bar{x}=215 \times 8.4 \mu \mathrm{m}, \mathrm{n}=30)$, cylindrical pedicellate $11-17.5 \times 3.5-4.3 \mu \mathrm{m}(\bar{x}=14 \times 3.9 \mu \mathrm{m}, \mathrm{n}=30)$. Ascospores uniseriate, partially overlapping, hyaline, fusiform, with rounded to acute ends, narrow towards apex, 3-septate, constricted at the central septum, with guttules in each cell, surrounded by an irregular 
and thin gelatinous sheath, 27.5-32 ×6.5-7.5 $\mu \mathrm{m}(\bar{x}=30 \times 7 \mu \mathrm{m}, \mathrm{n}=30)$. Asexual morph: Undetermined.

Culture characteristics: Colonies on PDA reaching $40 \mathrm{~mm}$ diam. after 4 weeks at $25^{\circ} \mathrm{C}$. Culture from above, brownish grey, forming zonate grey, fluffy mycelium at the edge; reverse dark brown, greyish orange at the edge.

Material examined: China, Sichuan Province, Chengdu City, Shuangliu District, Olive Base, $30^{\circ} 33.25^{\prime} \mathrm{N}, 103^{\circ} 99.62^{\prime} \mathrm{E}$, at an altitude of $438 \mathrm{~m}$ (mountainside), on dead branch of Olea europaea, 27 March 2021, W.L. Li, GL 139 (HKAS 121316, holotype; HUEST 21.0002, isotype), ex-type living culture CGMCC3.20618 = UESTCC 21.0002. Additional genes sequenced: ITS OK623480, RPB2 OK632627; ibid., T. Zhang, GL 136 (HUEST 21.0001, paratype), living culture UESTCC 21.0001. Additional genes sequenced: ITS OK623481, RPB2 OK632628.

Notes: Phylogenetic analysis showed that Melomastia fusispora is sister to $M$. winteri with high support (97\% ML BS, 100\% MP BS, 1.00 PP). Melomastia fusispora resembles $M$. winteri in having cylindrical asci and fusiform, 3-septate ascospores. However, M. fusispora has larger asci (200-231 vs. 165-189 $\mu \mathrm{m})$, pedicel (11-17.5 vs. $4.8-6.5 \mu \mathrm{m})$ and ascospore (27.5-32 vs. $25-30 \mu \mathrm{m}$ ) when compared to $M$. winteri. In addition, the ascospore ends of the Melomastia winteri are usually pointed, which differs from $M$. fusispora as the latter's ascospore has round to acute ends. A comparison of the 914 nucleotides across the $r p b 2$ gene region of $M$. fusispora (CGMCC3.20618) and M. winteri (CGMCC3.20621) reveals $39 \mathrm{bp}$ (base pair) differences $(4.26 \%)$. 

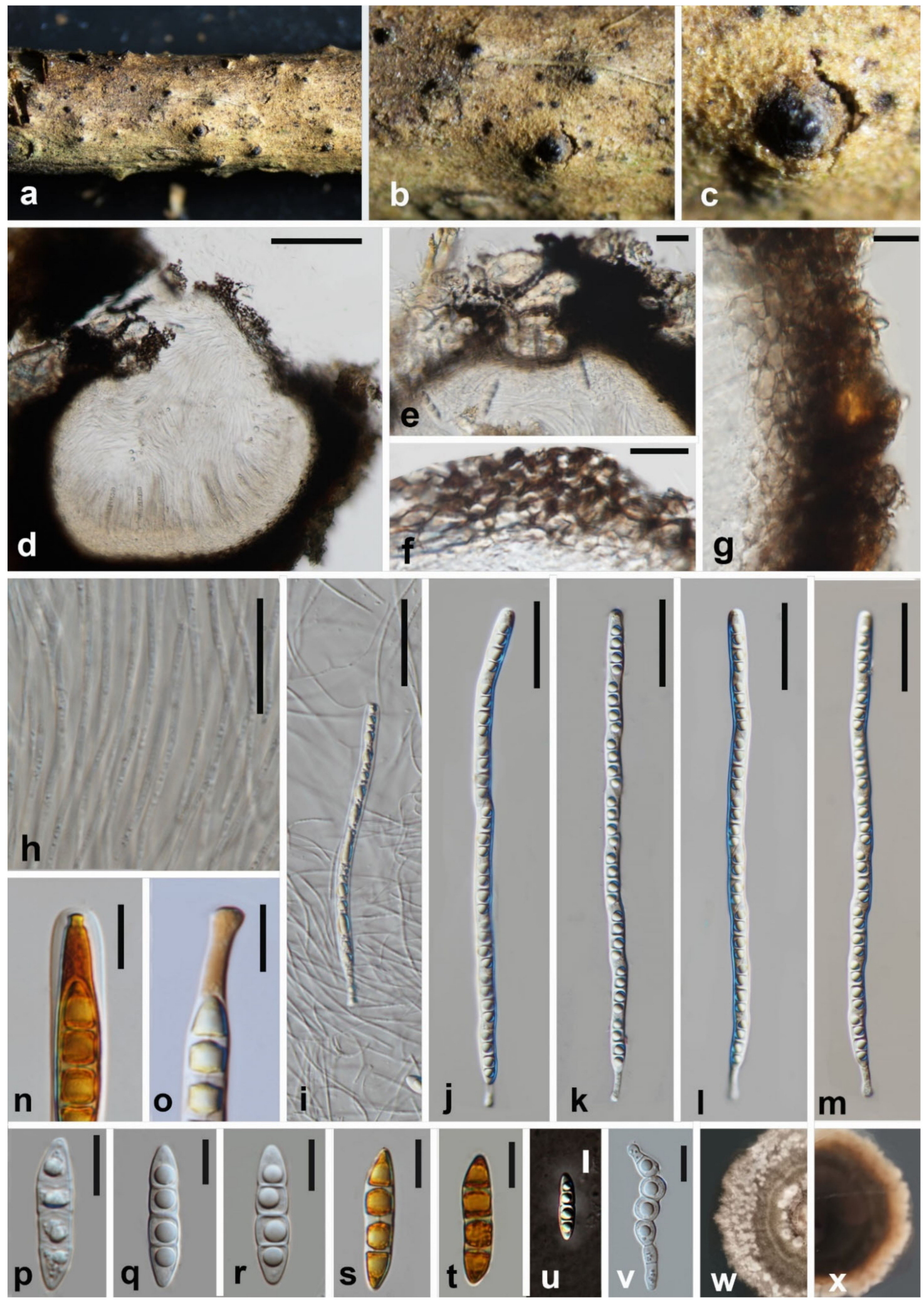

Figure 2. Melomastia fusispora (HKAS 121316, holotype). (a-c) Ascomata on the substrate. (d) Vertical section of the ascomata. (e) Vertical section of the ostiole. (f,g) Peridium (h) Pseudoparaphyses. (i-m) Asci. (n) Ocular chamber in Lugol's iodine. (o) Pedicel in Lugol's iodine. (p-u) Ascospora. ((s,t) in Lugol's iodine, (u) in India ink). (v) Germinating ascospore. (w) Upper view of the colony on PDA after 14d. (x) Reverse view of the colony on PDA after 14d. Scale bars: $(\mathbf{d})=100 \mu \mathrm{m}$, $(\mathbf{e}, \mathbf{g})=20 \mu \mathrm{m},(\mathbf{f}, \mathbf{n}-\mathbf{u})=10 \mu \mathrm{m},(\mathbf{h}-\mathbf{m})=40 \mu \mathrm{m}$. 
Melomastia oleae W.L. Li, Maharachch. \& Jian K. Liu, sp. nov. Figure 3.

MycoBank number: MB 841500; Facesoffungi number: FoF10534.

Etymology: The species epithet refers to the host genus on which it was collected.

Holotype: HKAS 121315.

Saprobic on dead branches of Olea europaea. Sexual morph: Ascomata visible as numerous, black, cone-shaped structures on host surface, solitary, gregarious, semi-immersed, globose to compressed globose, carbonaceous, dark brown to black, rough-walled, ostiolate, $410-440 \times 493-520 \mu \mathrm{m} .(\bar{x}=425 \times 506.5 \mu \mathrm{m}, \mathrm{n}=15)$. Ostioles neck crest-like, central, carbonaceous, dark brown to black, papillate, periphyses filling the ostiolar canal, 20.5-50 × 60-83 $\mu \mathrm{m}(\bar{x}=35 \times 72 \mu \mathrm{m}, \mathrm{n}=15)$. Peridium two-layered, outer thick, carbonaceous and inner composed of 5-6 layers of hyaline cells of textura angularis to textura prismatica, 54-65 $\mu \mathrm{m}$ wide. Hamathecium composed of numerous, dense, filiform, unbranched, aseptate pseudoparaphyses, 2-2.5 $\mu \mathrm{m}$ wide. Asci 8-spored, bitunicate, cylindrical, slightly flexuous, apically rounded with ocular chamber, 209-237 $\times 7.5-9 \mu \mathrm{m}(\bar{x}=223 \times 8 \mu \mathrm{m}$, $\mathrm{n}=30)$, cylindrical pedicellate $9-12 \times 3.5-5.8 \mu \mathrm{m}(\bar{x}=10.5 \times 4.6 \mu \mathrm{m})$. Ascospores uniseriate, partial overlapping, fusiform with obtuse ends, hyaline, 3-septate, slightly constricted at the septa, with guttules in each cell, 28-34 ×6-7 $\mu \mathrm{m}(\bar{x}=31 \times 6.5 \mu \mathrm{m}, \mathrm{n}=30)$. Asexual morph: Undetermined.

Culture characteristics: Colonies on PDA reaching $15 \mathrm{~mm}$ diam. after 2 weeks at $25{ }^{\circ} \mathrm{C}$. Cultures from above white, dense, circular, margin entire, papillate; reverse dark brown.

Material examined: China, Sichuan Province, Chengdu City, Shuangliu District, Olive Base, $30^{\circ} 33.25^{\prime} \mathrm{N}, 103^{\circ} 99.62^{\prime} \mathrm{E}$, at an altitude of $432 \mathrm{~m}$ (the foot of mountain), 30 January 2021, on dead branch of Olea europaea, W.L. Li, GL 031 (HKAS 121315, holotype; HUEST 21.0004, isotype), ex-type living culture CGMCC3.20619 = UESTCC 21.0004. Additional genes sequenced: ITS OK623482; ibid., T. Zhang, GL 004 (HUEST 21.0003, paratype), living culture UESTCC 21.0003; ibid., at an altitude of $438 \mathrm{~m}$ (Mountain side), 27 March 2021, on dead branch of Olea europaea, W.L. Li, GL 128 (HUEST 21.0005, paratype isotype), living culture UESTCC 21.0005. Additional genes sequenced: ITS OK623483; ibid., Z.P. Liu, GL 135 (HUEST 21.0006, paratype), living culture UESTCC 21.0006. Additional genes sequenced: ITS OK623484.

Notes: Phylogenetic analysis results showed that Melomastia oleae clustered with M. fusispora, M. thamplaensis and $M$. winteri, but represented a distinct clade with high support (100\% ML BS, 100\% MP BS, 1.00 PP). Melomastia oleae share similar ascus and ascospore morphology with $M$. fusispora, $M$. thamplaensis and $M$. winteri. However, $M$. winteri and $M$. thamplaensis have shorter asci than M. oleae (165-189 $\mu \mathrm{m}$ vs. 114-160 $\mu \mathrm{m}$ vs. 209-237 $\mu \mathrm{m})$. Melomastia fusispora is easily differentiated from M. oleae by having noncarbonised peridium and relatively lager ascomata $(528 \times 572 \mu \mathrm{m}$ vs. $425 \times 506.5 \mu \mathrm{m})$. Additionally, tef1- $\alpha$ sequence comparison reveals 48 bp differences without gaps across 875 nucleotides $(5.48 \%$ ) between Melomastia fusispora and M. oleae. 


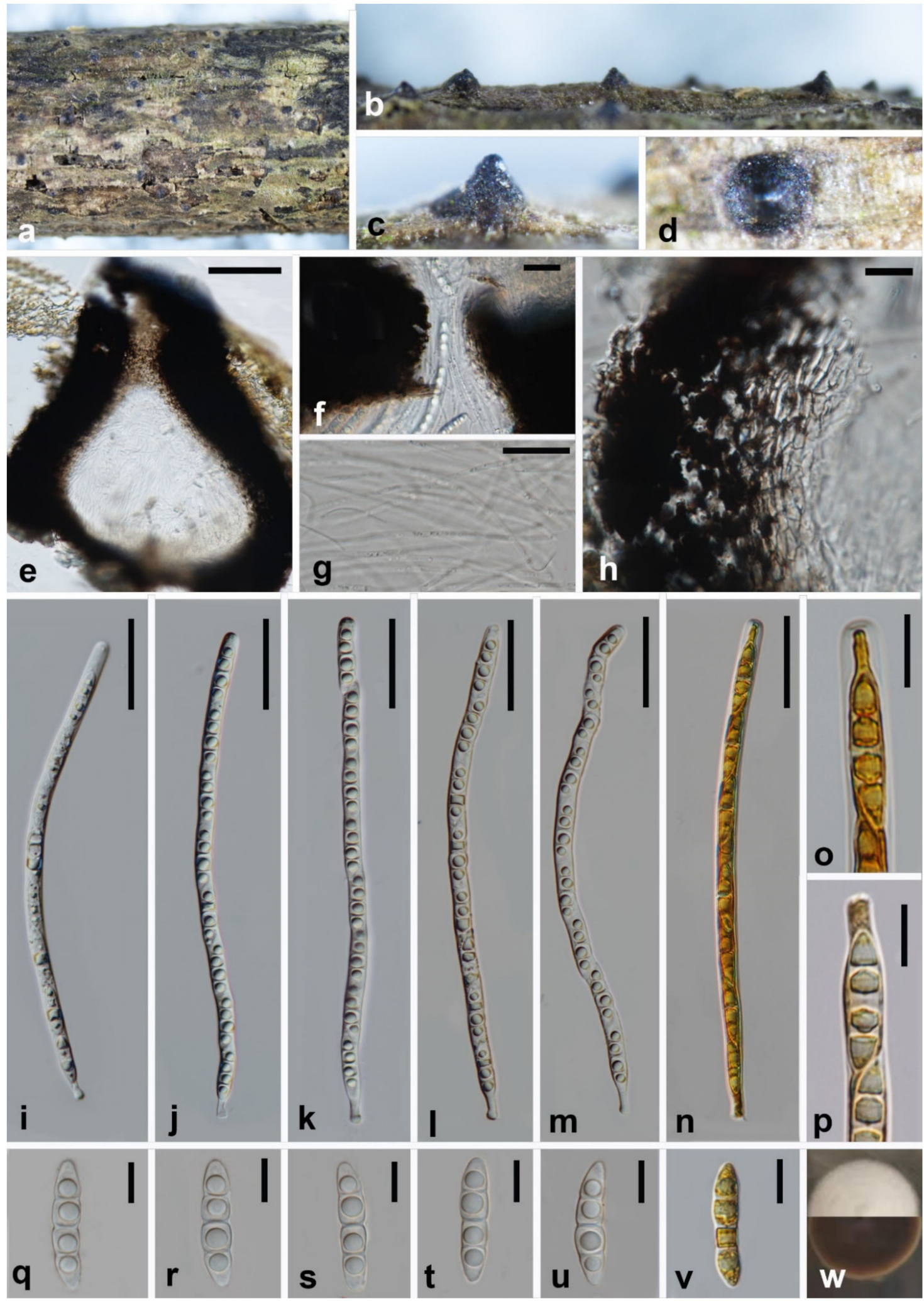

Figure 3. Melomastia oleae (HKAS 121315, holotype). (a-d) Ascomata on the substrate. (e) Verticle section of the ascoma. (f) Vertical section of the ostiole. (g) Pseudoparaphyses. (h) Peridium. (i-n) Asci ((n) in Lugol's iodine). (o) ocular chamber in Lugol's iodine. (p) pedicel in Lugol's iodine. (q-v) Ascospora ((v) in Lugol's iodine). (w) Upper and reverse view of the colony on PDA after 14d. Scale bars: $(\mathbf{e})=100 \mu \mathrm{m},(\mathbf{f})=20 \mu \mathrm{m},(\mathbf{g}, \mathbf{h}, \mathbf{o}-\mathbf{v})=10 \mu \mathrm{m},(\mathbf{i}-\mathbf{n})=40 \mu \mathrm{m}$. 
Melomastia sichuanensis W.L. Li, Maharachch. and Jian K. Liu, sp. nov. Figure 4. MycoBank number: MB841501; Facesoffungi number: FoF10535.

Etymology: Refers to the place where the type species was collected.

Holotype: HKAS 121313.

Saprobic on dead branches of Olea europaea. Sexual morph: Ascomata only ostioles visible at the surface of host, solitary, gregarious, immersed, globose to subglobose, pseudothecia, coriaceous to carbonaceous, dark brown to black, rough-walled, ostiolate, $419.5-506 \times 335-577 \mu \mathrm{m}(\bar{x}=462.5 \times 456 \mu \mathrm{m}, \mathrm{n}=15)$. Ostioles central, carbonaceous, dark brown to black, papillate, periphyses filling the ostiolar canal, 90-120 $\times 85-110 \mu \mathrm{m}$ $(\bar{x}=105 \times 97.5 \mu \mathrm{m}, \mathrm{n}=15)$. Clypeus black, thick-walled. Peridium two-layered, an outer layer of cells of textura intricata composed of host cells interspersed with fungal hyphae, carbonaceous and the inner layer comprising lightly brown cells and thin, 44-85.5 $\mu \mathrm{m}$ $(\bar{x}=65 \mu \mathrm{m}, \mathrm{n}=15)$ wide. Hamathecium composed of numerous, dense, filiform, unbranched, septate, cellular pseudoparaphyses, 2.5-3.7 $\mu \mathrm{m}(\bar{x}=3.1 \mu \mathrm{m}, \mathrm{n}=15)$ wide. Asci 8-spored, bitunicate, cylindrical, apically round, with a small ocular chamber, $101-112.5 \times 6.5-7.6 \mu \mathrm{m}$ $(\bar{x}=107 \times 7 \mu \mathrm{m}, \mathrm{n}=30)$, cylindrical pedicellate $3.5-7 \times 3.2-3.8 \mu \mathrm{m}(\bar{x}=5.3 \times 3.5 \mu \mathrm{m}$, $\mathrm{n}=30)$. Ascospores uniseriate, partial overlapping, broad fusiform with rounded ends, hyaline, 3-septate, constricted at the septa, with guttules in each cell, smooth-walled with mucilaginous sheath, $15-17.5 \times 4.7-5.1 \mu \mathrm{m}(\bar{x}=16 \times 5 \mu \mathrm{m}, \mathrm{n}=30)$. Asexual morph: Undetermined.

Culture characteristics. Colonies on PDA reaching $30 \mathrm{~mm}$ diam. after 4 weeks at $25{ }^{\circ} \mathrm{C}$. Culture from above, yellowish radiating outwardly, with yellow ring in the middle, medium dense, circular shape, covered with cream mycelium; reverse: brown in the middle with an orange ring, dark yellow radiating outwardly.

Material examined: China, Sichuan Province, Chengdu City, Shuangliu District, Olive Base, $30^{\circ} 33.25^{\prime} \mathrm{N}, 103^{\circ} 99.62^{\prime} \mathrm{E}$, at an altitude of $432 \mathrm{~m}$ (the foot of mountain), 30 January 2021, W.L. Li, GL 001 (HKAS 121313, holotype; HUEST 21.0007, isotype), ex-type living culture CGMCC3.20620 = UESTCC 21.0007. Additional genes sequenced: RPB2 OK632629; ibid., Z.P. Liu, GL 005 (HUEST 21.0008, paratype), living culture, UESTCC 21.0008. Additional genes sequenced: RPB2 OK632630.

Notes: Phylogenetic analysis results showed that Melomastia sichuanensis formed a moderately supported clade sister to $M$. clematidis (92\% ML BS, 86\% MP BS, $1.00 \mathrm{BI}$ ). In addition, the comparison of tef1- $\alpha$ sequence data between the two species showed 46 nucleotides differences without gaps across the 878 nucleotides (5.24\%), but only $1 \mathrm{bp}$ difference across 829 nucleotides of LSU and 2 bp differences across the 766 nucleotides of SSU. Morphologically, M. sichuanensis resembles M. clematidis in having 3-septate ascospore with a thin mucilaginous sheath, but $M$. sichuanensis can be distinguished from $M$. clematidis in its shorter asci (101-112.5 $\mu \mathrm{m}$ vs. 115-160 $\mu \mathrm{m})$. In addition, M. clematidis has ellipsoidal to fusiform ascospores with acute ends, while they are broad fusiform with rounded ends in M. sichuanensis [19]. 

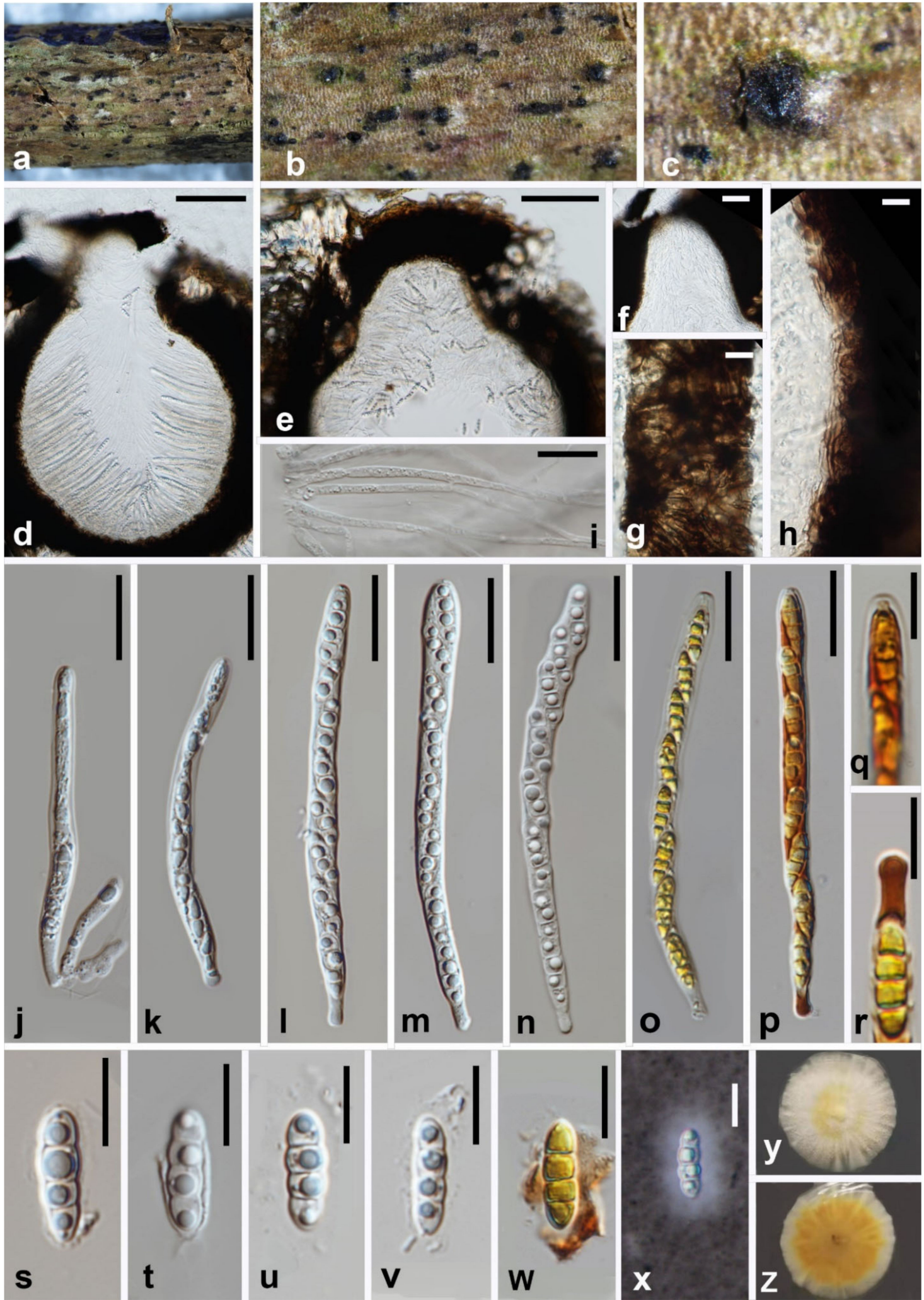

Figure 4. Melomastia sichuanensis (HKAS 121313, holotype). (a-c) Ascomata on the substrate. (d,e) Vertical section of ascoma. (f) Vertical section of ostiole. (g,h) Peridium. (i) Pseudoparaphyses. $(\mathbf{j}-\mathbf{p})$ Asci ((o,p) in Lugol's iodine). (q) ocular chamber in Lugol's iodine. (r) pedicel in Lugol's iodine. $(\mathbf{s}-\mathbf{x})$ Ascospora $((\mathbf{w})$ in Lugol's iodine, $\mathbf{x}$ in India ink). $(\mathbf{y}, \mathbf{z})$ Upper and reverse view of the colony on PDA after 14d. Scale bars: $(\mathbf{d}, \mathbf{e})=100 \mu \mathrm{m},(\mathbf{f})=40 \mu \mathrm{m},(\mathbf{g}, \mathbf{h}, \mathbf{q}-\mathbf{x})=10 \mu \mathrm{m},(\mathbf{i}-\mathbf{p})=20 \mu \mathrm{m}$. 
Melomastia winteri W.L. Li, Maharachch. \& Jian K. Liu, sp. nov. Figure 5.

MycoBank number: MB841502; Facesoffungi number: FoF10536.

Etymology: The epithet "winteri" refers to the season when the fungus was collected.

Holotype: HKAS 121314.

Saprobic on dead branches of Olea europaea. Sexual morph Ascomata solitary, gregarious, semi-immersed to immersed, globose, coriaceous to carbonaceous, dark brown to black, ostiolate, $340-365 \times 364-410 \mu \mathrm{m}(\bar{x}=352 \times 387 \mu \mathrm{m}, \mathrm{n}=15)$. Ostioles central, coriaceous to carbonaceous, dark brown to black, papillate, periphyses filling the ostiolar canal, 105-108 × 106-113 $\mu \mathrm{m}(\bar{x}=106.5 \times 109.5 \mu \mathrm{m}, \mathrm{n}=10)$. Peridium two-layered, outer thick, carbonaceous and inner composed of 3-4 layers of hyaline to lightly brown cells of textura angularis to textura prismatica, 55-62.5 $\mu \mathrm{m}(\bar{x}=59 \mu \mathrm{m}, \mathrm{n}=10)$ wide. Hamathecium composed of numerous, dense, filiform, unbranched, septate, cellular pseudoparaphyses, 1.5-3.5 $\mu \mathrm{m}$ wide. Asci 8-spored, bitunicate, cylindrical, slightly flexuous, apically round, with a distinct ocular chamber, $165-189 \times 7-8.5 \mu \mathrm{m}(\bar{x}=177 \times 7.5 \mu \mathrm{m}, \mathrm{n}=30)$, cylindrical pedicellate $4.8-6.5 \times 3.5-4.6 \mu \mathrm{m}(\bar{x}=5.6 \times 4 \mu \mathrm{m}, \mathrm{n}=30)$. Ascospores uniseriate, partially overlapping, fusiform with acute ends, hyaline, 3-septate, deeply constricted at the median septum, with guttules in each cell, lacking a mucilaginous sheath, 25-30 × 5-6.5 $\mu \mathrm{m}(\bar{x}=27.5 \times 6 \mu \mathrm{m}$, $\mathrm{n}=30$ ). Asexual morph: Undetermined.

Culture characteristics: Colonies on PDA reaching $30 \mathrm{~mm}$ diam. after 4 weeks at $25{ }^{\circ} \mathrm{C}$. Cultures from above, white, dense, circular, margin erose, umbonate, papillate with somewhat fluffy, pale orange at the center; reverse dark brown at the center, pale yellow at the edge.

Material examined: China, Sichuan Province, Chengdu City, Shuangliu District, Olive Base, $30^{\circ} 33.25^{\prime} \mathrm{N}, 103^{\circ} 99.62^{\prime} \mathrm{E}$, at an altitude of $432 \mathrm{~m}$ (the foot of the mountain), 29 January 2021, W.L. Li, GL 010 (HKAS 121314, holotype; HUEST 21.0009, isotype); extype living culture CGMCC3.20621 = UESTCC 21.0009. Additional genes sequenced: ITS OK623485, RPB2 OK632631.

Notes: Phylogenetic analysis showed that Melomastia winteri clustered with $M$. fusispora (97\% ML BS, 100\% MP BS, $1.00 \mathrm{BI})$. Morphologically, M. winteri is similar to $M$. fusispora in having 3-septate fusiform ascospore. However, $M$. fusispora can be distinguished from M. winteri by its larger ascomata $(432-624 \times 527-618 \mu \mathrm{m}$ vs. $340-365 \times 364-410 \mu \mathrm{m})$ and

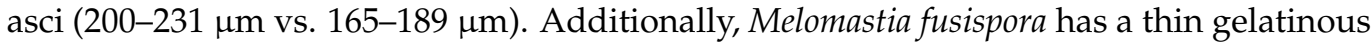
sheath around the ascospores, which is not observed in M. winteri. 

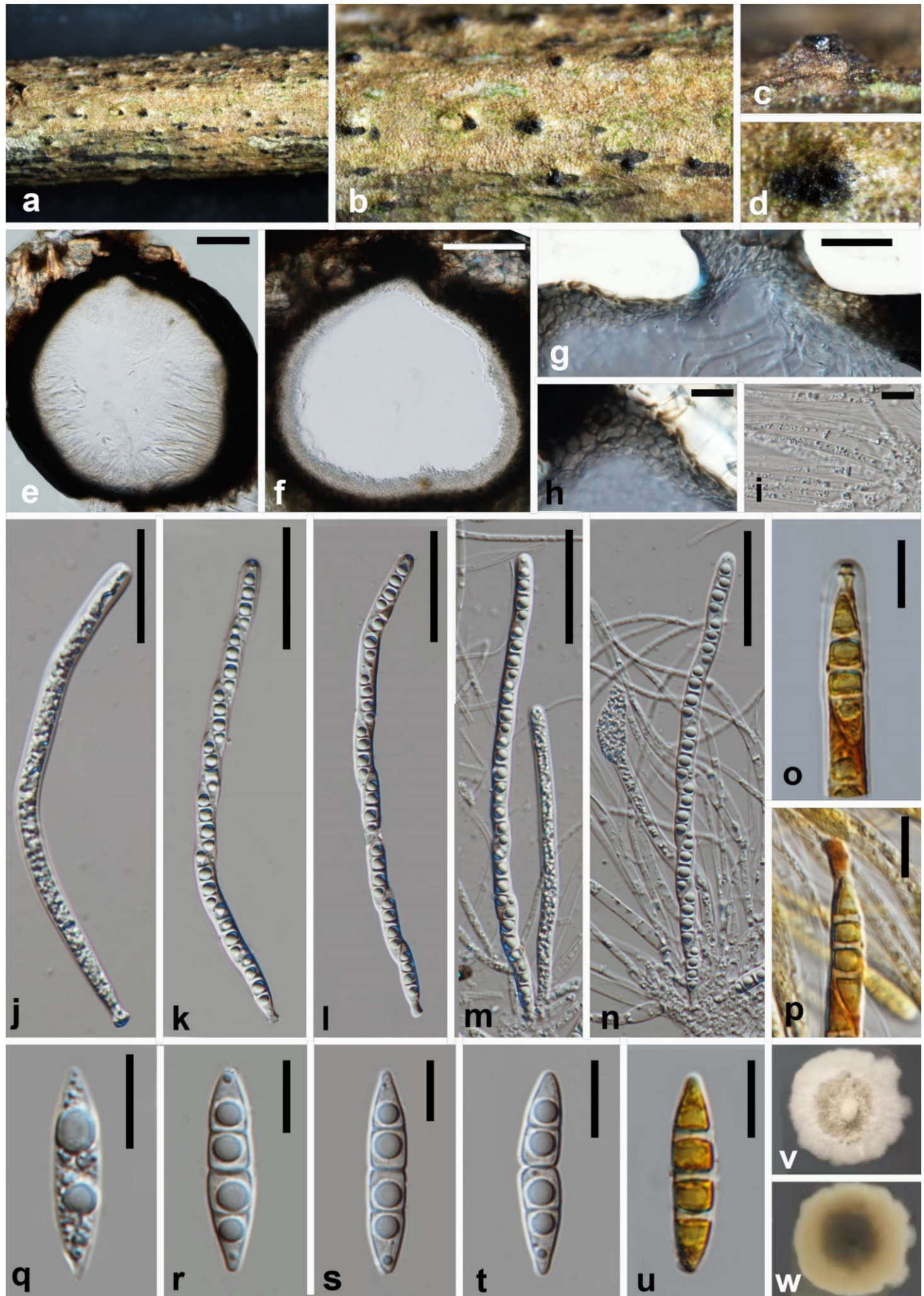

Figure 5. Melomastia winteri (HKAS 121314, holotype). (a-d) Ascomata on the substrate. (e,f) Vertical of the ascoma. (g) Vertical section of the ostiole. (h) Peridium. (i) Pseudoparaphyses. (j-n) Asci. (o) Ocular chamber in Lugol's iodine. (p) Pedicel in Lugol's iodine. (q-u) Ascospora $((\mathbf{u})$ in Lugol's iodine). $(\mathbf{v}, \mathbf{w})$ Upper and reverse view of the colony on PDA after $14 \mathrm{~d}$. Scale bars: $(\mathbf{e}, \mathbf{f})=100 \mu \mathrm{m},(\mathbf{g}, \mathbf{h}, \mathbf{i}, \mathbf{o}-\mathbf{u})=10 \mu \mathrm{m},(\mathbf{j}-\mathbf{n})=40 \mu \mathrm{m}$. 


\subsubsection{New Combination}

Melomastia aquatica (K. M. Tsui, K.D. Hyde, I.J. Hodgkiss and Goh) W.L. Li, Maharachch. \& Jian K. Liu, comb. nov. 三Saccardoella aquatica K.M. Tsui, K.D. Hyde, I.J. Hodgkiss, T.K. Goh, Mycologia 90(4): 701, 1998.

$=$ Dyfrolomyces aquaticus (K.M. Tsui, K.D. Hyde, I.J. Hodgkiss, T.K. Goh) J.F. Zhang, J.K. Liu, K.D. Hyde \& Z.Y. Liu, Phytotaxa 313 (3): 267-277, 2017. MycoBank: MB 842085.

Melomastia chromolaenae (Mapook \& K.D. Hyde) W.L. Li, Maharachch. \& Jian K. Liu, comb. nov.

$\equiv$ Dyfrolomyces chromolaenae Mapook \& K.D. Hyde, Fungal Diversity 101: 1-175, 2020. MycoBank: MB 842086.

Melomastia distoseptata (M. Niranjan \& V.V Sarma) W.L. Li, Maharachch. \& Jian K. Liu, comb. nov.

$\equiv$ Dyfrolomyces distoseptatus M. Niranjan \& V.V Sarma, Fungal Diversity 105: 17-318, 2020. MycoBank: MB 842087.

Melomastia mangrovei (K.D. Hyde) W.L. Li, Maharachch. \& Jian K. Liu, comb. nov. 三Saccardoella mangrovei K.D. Hyde, Mycologia, 84(5), 806, 1992.

$=$ Dyfrolomyces mangrovei (K.D. Hyde) K.D. Hyde, K.L. Pang, Alias, Suetrong \& E.B.G. Jones, Cryptogamie, Mycologie, 2017, 38 (4): 507-525.

MycoBank: MB 842088.

Melomastia marinospora (K.D. Hyde) W.L. Li, Maharachch. \& Jian K. Liu, comb. nov. 三Saccardoella marinospora K.D. Hyde, Mycologia 84(5): 803-806, 1992.

$=$ Dyfrolomyces marinosporus (K.D. Hyde) K.D. Hyde, K.L. Pang, Alias, Suetrong \&

E.B.G. Jones, Cryptogamie, Mycologie, 2017, 38 (4): 507-525.

MycoBank: MB 842089.

Melomastia neothailandica (Dayarathne Jones E.B.G. and K.D. Hyde) W.L. Li, Maharachch. \& Jian K. Liu, comb. nov. $\equiv$ Dyfrolomyces neothailandicus Dayarathne Jones E.B.G. and K.D. Hyde, Mycosphere 11(1): 1-188, 2020.

MycoBank: MB 842090.

Melomastia phetchaburiensis (Dayarathne, Jones E.B.G. and K.D. Hyde) W.L. Li, Maharachch. \& Jian K. Liu, comb. nov.

$\equiv$ Dyfrolomyces phetchaburiensis Dayarathne, Jones E.B.G. and K.D. Hyde, Fungal Diversity 87: 33, 2017.

MycoBank: MB 842091

Melomastia rhizophorae (K.D. Hyde) W.L. Li, Maharachch. \& Jian K. Liu, comb. nov. 三Saccardoella rhizophorae K.D. Hyde, Mycologia 84(5): 806, 1992.

$=$ Dyfrolomyces rhizophorae (K.D. Hyde) K.D. Hyde, K.L. Pang, Alias, Suetrong \& E.B.G. Jones, Cryptogamie, Mycologie, 2017, 38 (4): 507-525.

MycoBank: MB 842092.

Melomastia sinensis (Samarak., Tennakoon and K.D. Hyde) W.L. Li, Maharachch. \& Jian K. Liu, comb. nov.

EDyfrolomyces sinensis Samarak., Tennakoon and K.D. Hyde, Mycosphere 9(2): 354, 2018. MycoBank: MB 842093.

Melomastia thailandica (Dayarathne, Jones E.B.G. and K.D. Hyde) W.L. Li, Maharachch. and Jian K. Liu, comb. nov.

$\equiv$ Pleurotrema thailandica Dayarathne, Jones E.B.G. and K.D. Hyde, Fungal Diversity 81: 131, 2016.

MycoBank: MB 842094.

Melomastia thamplaensis (J.F. Zhang, J.K. Liu, K.D. Hyde and Z.Y. Liu) W.L. Li, Maharachch. and Jian K. Liu, comb. nov.

$\equiv$ Dyfrolomyces thamplaensis J.F. Zhang, J.K. Liu, K.D. Hyde and Z.Y. Liu, Phytotaxa 313

(3): 267-277. 
MycoBank: MB 842095.

Melomastia tiomanensis (K.L. Pang, S.A. Alias, K.D. Hyde, Suetrong and E.B.G. Jones) W.L. Li, Maharachch. and Jian K. Liu, comb. nov.

$\equiv$ Dyfrolomyces tiomanensis K.L. Pang, S.A. Alias, K.D. Hyde, Suetrong and E.B.G. Jones, Cryptogamie, Mycologie, 2013, 34 (1): 223-232.

MycoBank: MB 842096.

\section{Discussion}

Species of Melomastia have a wide geographical distribution, e.g., Africa, China, Germany, Italy, Japan, Poland and the United States of America (California) [18], and are reported in marine, freshwater and terrestrial habitats $[9,20,28]$; they do not seem to have specific host preferences. Though a few species are known as saprophytes on mangrove wood (Avicennia marina, Kandelia, Rhizophora sp.), the rest are reported from various woody hosts (eg. Clematis sp., Chromolaena odorata and Vitis vinifera) [18]. This study provides the first report of Melomastia species reported from Olea europaea.

A well-resolved revision of the family Pleurotremataceae is challenging since the type species of the early established genera Melomastia and Pleurotrema do not possess molecular data. Norphanphoum et al. [18] proposed combining Dyfrolomyces and Pleurotrema under Melomastia based on similar phenotypic characteristics, and they suggested this taxonomic assumption needs to be reinforced via increasing the number of taxa with sequence data in each genus. In the present study, we have included the taxa representing all species of Pleurotremataceae (of which the sequences are available in GenBank) and nine pleurotrema-like taxa obtained from olive. Considering the morphological comparison (Table 2) and multi-gene phylogenetic analysis (Figure 1), Melomastia and Dyfrolomyces are congeneric, and the epithet Melomastia should be adopted as it is the oldest name. Further studies with more collections of Pleurotremataceae, especially of Melomastia mastoidea and Pleurotrema polysemum are essential for a better understanding of the taxonomic relationship of this family.

Table 2. Synopsis of morphological characteristics, habitats and hosts compared across Melomastia species.

\begin{tabular}{|c|c|c|c|c|c|c|c|c|}
\hline \multirow{2}{*}{ Taxa } & \multirow{2}{*}{ Asci Size $(\mu \mathrm{m})$} & \multicolumn{2}{|c|}{ Ascospores } & \multirow{2}{*}{$\begin{array}{c}\text { Septa in } \\
\text { Ascospores }\end{array}$} & \multirow{2}{*}{ Sheath } & \multirow{2}{*}{$\begin{array}{l}\text { Habitats \& Host } \\
\text { Records }\end{array}$} & \multirow{2}{*}{ Location } & \multirow{2}{*}{ References } \\
\hline & & Morphology & Size $(\mu \mathrm{m})$ & & & & & \\
\hline $\begin{array}{l}\text { Melomastia } \\
\text { aquatica }\end{array}$ & $185-230 \times 7-9$ & Fusiform & $26-34 \times 6-8$ & 3 & Yes & Freshwater/Unknown & China & [9] \\
\hline M. chromolaenae & $135-160 \times 7-8$ & Fusiform & $29-35 \times 4.5-6$ & $9-11$ & No & $\begin{array}{l}\text { Terrestrial/Chromolaena } \\
\text { odorata }\end{array}$ & Thailand & {$[42]$} \\
\hline M. clematidis & $115-160 \times 4-7$ & $\begin{array}{c}\text { Broad } \\
\text { fusiform with } \\
\text { acute ends }\end{array}$ & $13-20 \times 3.8-5$ & 3 & Yes & $\begin{array}{l}\text { Terrestrial/Clematis } \\
\text { sikkimensis }\end{array}$ & Thailand & [19] \\
\hline M. distoseptata & $\begin{array}{c}126.7-146.2 \times \\
4.7-6.3 \\
\end{array}$ & $\begin{array}{l}\text { Fusoid, obtuse } \\
\text { ends }\end{array}$ & $19.7-24.9 \times 4.3-5$ & 3 & No & Terrestrial/Unknown & Andaman & [15] \\
\hline M. fulvicomae & $70-90 \times 4-6$ & $\begin{array}{l}\text { Broad } \\
\text { fusiform with } \\
\text { rounded ends, } \\
\text { ends acute }\end{array}$ & $9-15 \times 3.5-5.5$ & $2-3$ & Yes & $\begin{array}{l}\text { Terrestrial/Clematis } \\
\text { fulvicoma }\end{array}$ & Thailand & [19] \\
\hline M. fusispora & $200-231 \times 7.6-9.2$ & Fusiform & $27.5-32 \times 6.5-7.5$ & 3 & Yes & $\begin{array}{c}\text { Terrestrial/Olea } \\
\text { europaea }\end{array}$ & China & this study \\
\hline M. italica & $120-190 \times 5.1-8.9$ & Ellipsoidal & $8.8-10.5 \times 2.8-4.11$ & 2 & Yes & $\begin{array}{l}\text { Terrestrial/Vitis } \\
\text { vinifera }\end{array}$ & Italy & [18] \\
\hline M. mangrovei & $154-216 \times 8.5-14$ & Fusiform & $26-33 \times 6-8$ & $7-9$ & Yes & $\begin{array}{l}\text { Intertidal/Rhizophora } \\
\text { sp. }\end{array}$ & Thailand & [21] \\
\hline M. maolanensis & $\begin{array}{l}(95-) 103-118 \\
(-122) \times 4-5.5\end{array}$ & $\begin{array}{l}\text { Fusiform with } \\
\text { round ends }\end{array}$ & $13.5-18 \times 3.5-4.5$ & 3 & No & Terrestrial/Unknown & China & [28] \\
\hline M. marinospora & $190-240 \times 10-12$ & $\begin{array}{l}\text { Cylindrical } \\
\text { with acute } \\
\text { poles }\end{array}$ & $25-31 \times 7.5-10$ & 3 & Yes & $\begin{array}{l}\text { Intertidal/Kandelia } \\
\text { candel }\end{array}$ & Brunei & {$[21]$} \\
\hline M. neothailandica & $165-190 \times 10-12$ & Ellipsoidal & $26-28 \times 7.2-8$ & 5 & Yes & $\begin{array}{c}\text { Marine/Rhizophora } \\
\text { sp. }\end{array}$ & Thailand & {$[43]$} \\
\hline
\end{tabular}


Table 2. Cont.

\begin{tabular}{|c|c|c|c|c|c|c|c|c|}
\hline \multirow{2}{*}{ Taxa } & \multirow{2}{*}{ Asci Size $(\mu \mathrm{m})$} & \multicolumn{2}{|c|}{ Ascospores } & \multirow{2}{*}{$\begin{array}{c}\text { Septa in } \\
\text { Ascospores }\end{array}$} & \multirow{2}{*}{ Sheath } & \multirow{2}{*}{$\begin{array}{l}\text { Habitats \& Host } \\
\text { Records }\end{array}$} & \multirow{2}{*}{ Location } & \multirow{2}{*}{ References } \\
\hline & & Morphology & Size $(\mu \mathrm{m})$ & & & & & \\
\hline M. oleae & $209-237 \times 7.5-9$ & $\begin{array}{l}\text { Fusiform, } \\
\text { obtuse ends }\end{array}$ & $28-34 \times 6-7$ & 3 & No & $\begin{array}{c}\text { Terrestrial/Olea } \\
\text { europaea }\end{array}$ & China & this study \\
\hline $\begin{array}{c}\text { M. } \\
\text { phetchaburiensis }\end{array}$ & $190-300 \times 8-12$ & Ellipsoidal & $35-40 \times 5-10$ & $1-10$ & No & $\begin{array}{l}\text { Marine/Rhizophora } \\
\text { apiculata }\end{array}$ & Thailand & [44] \\
\hline M. rhizophorae & $135-160 \times 8-10$ & Ellipsoidal & $19-26 \times 6-8$ & $4-6$ & Yes & $\begin{array}{l}\text { Intertidal/Rhizophora } \\
\text { apiculata }\end{array}$ & Thailand & [9] \\
\hline M. sichuanensis & $101-112.5 \times 6.5-7.6$ & $\begin{array}{c}\text { Broad } \\
\text { fusiform with } \\
\text { rounded ends }\end{array}$ & $15-17.5 \times 4.7-5.1$ & 3 & Yes & $\begin{array}{c}\text { Terrestrial/Olea } \\
\text { europaea }\end{array}$ & China & this study \\
\hline M. sinensis & $160-220 \times 8-10$ & Cylindrical & $18-30 \times 5-8$ & $6-7$ & No & $\begin{array}{c}\text { Terrestrial/Camellia } \\
\text { sinensis }\end{array}$ & Thailand & [45] \\
\hline M. thailandica & $146-158 \times 7-9$ & Ellipsoidal & $24-32 \times 6-8$ & $3-5$ & Yes & $\begin{array}{l}\text { Marine/Avicennia } \\
\text { marina }\end{array}$ & Thailand & [46] \\
\hline M. thamplaensis & $114-160 \times 6-8.5$ & $\begin{array}{l}\text { Fusiform with } \\
\text { acute angular } \\
\text { ends }\end{array}$ & $19.5-23.5 \times 5-6.5$ & 3 & No & Terrestrial/Unknown & China & [28] \\
\hline M. tiomanensis & $316-333 \times 12-17$ & $\begin{array}{l}\text { Spindle- } \\
\text { shaped }\end{array}$ & $69-82 \times 9-11$ & $6-7$ & No & $\begin{array}{l}\text { Terrestrial/Rhizophora } \\
\text { sp. }\end{array}$ & Malaysia & [20] \\
\hline M. winteri & $165-189 \times 7-8.5$ & $\begin{array}{l}\text { Fusiform with } \\
\text { acute ends }\end{array}$ & $25-30 \times 5-6.5$ & 3 & No & $\begin{array}{c}\text { Terrestrial/Olea } \\
\text { europaea }\end{array}$ & China & this study \\
\hline
\end{tabular}

The differences between the peridium of the ascomata and ascomatal position on the substrate probably play prominent roles in differentiating some fungal groups $[56,57]$. However, the results of this study suggest that it may also vary depending on the condition of habitats (terrestrial or aquatic environment) and substrates (herbaceous or woody plants), e.g., Melomastia produce fully immersed ascomata in an aquatic habitat (M. tiomanensis) and superficial or semi-erumpent ascomata in a terrestrial environment (e.g., M. fusispora, and M. sinensis) [45]; the peridium (perithecia) of the ascomata on woody plants is composed of 2-zone (e.g., M. oleae, M. sichuanensis), while those on herbaceous plants or semi-woody were 1-zone (e.g., M. chromolaenae, M. italica) [18,42]. Thus, the ascomatal position on the substrate and the zonation of the peridium of the ascomata have no taxonomic significance for generic delimitation in Pleurotremataceae, and could even change depending on the host and location.

\section{Conclusions}

This study comprises research investigating fungi associated with oil trees in Sichuan Province in China, and here we introduced four new species of Pleurotremataceae isolated from olive (Olea europaea). With detailed descriptions, Dyfrolomyces was synonymized under Melomastia based on molecular phylogeny and morphology. Olives are cultivated in many regions of the world with Mediterranean climates, such as Australia, Chile, Italy, Peru, South Africa and the USA (California and Oregon). This study represents the first discovery of Melomastia on the Olea europaea in China.

Author Contributions: Methodology, J.-K.L. and W.-L.L.; formal analysis, W.-L.L., S.S.N.M. and J.-K.L.; resources, W.-L.L. and J.-K.L.; data curation, W.-L.L., R.C. and J.-K.L., writing-original draft preparation, W.-L.L.; writing-review and editing, W.-L.L., S.S.N.M. and J.-K.L.; supervision, J.-K.L.; project administration, J.-K.L.; funding acquisition, J.-K.L. All authors have read and agreed to the published version of the manuscript.

Funding: This study is supported by the Joint Fund of the National Natural Science Foundation of China and the Karst Science Research Center of Guizhou province (Grant No. U1812401).

Institutional Review Board Statement: Not applicable.

Informed Consent Statement: Not applicable. 
Data Availability Statement: All sequence data are available in NCBI GenBank following the accession numbers in the manuscript.

Acknowledgments: Asha J. Dissanayake and E.B. Gareth Jones are thanked for the suggestions on the manuscript.

Conflicts of Interest: The authors declare no conflict of interests.

\section{References}

1. Watson, W. The classification of lichens. New Phytol. 1929, 28, 85-116. [CrossRef]

2. Barr, M.E. Notes on the Amphisphaeriaceae and related families. Mycotaxon 1994, 51, 191-224.

3. Kirk, P.M.; Cannon, P.F.; Minter, D.W.; Stalpers, J.A. Ainsworth E Bisby's Dictionary of the Fungi, 10th ed.; CABI: Oxford, UK, 2008.

4. Senanayake, I.; Al-Sadi, A.; Bhat, J.; Camporesi, E.; Dissanayake, A.; Lumyong, S.; Maharachchikumbura, S.; Hyde, K. Phomatosporales ord. nov. and Phomatosporaceae fam. nov., to accommodate Lanspora, Phomatospora and Tenuimurus, gen. nov. Mycosphere 2016, 7, 628-641. [CrossRef]

5. Kirk, P.M.; Cannon, P.F.; David, J.C.; Stalpers, J.A. Ainsworth and Bisby's Dictionary of the Fungi, 8th ed.; CABI: London, UK, 2001.

6. Lumbsch, H.T.; Huhndorf, S.M. Myconet Volume 14. Part One. Outline of Ascomycota-2009. Part Two. Notes on Ascomycete Systematics. Nos. 4751-5113. Fieldiana Life Earth Sci. 2010, 2010, 1-64. [CrossRef]

7. Hawksworth, D.L.; Kirk, P.M.; Sutton, B.C.; Pegler, D.N. Dictionary of the Fungi, 8th ed.; CABI: Oxford, UK, 1995.

8. Mathiassen, G. Some Corticolous and Lignicolous Pyrenomycetes s. lat. (Ascomycetes) on Salix in Troms, N Norway; Botanical Garden and Museum, University of Oslo: Oslo, Norway, 1989.

9. Hyde, K.D. The genus Saccardoella from intertidal mangrove wood. Mycologia 1992, 84, 803-810. [CrossRef]

10. Barr, M. The genus Dothidotthia (Botryosphaeriaceae) in North America. Mycotaxon 1989, 34, 517-526.

11. Aptroot, A. A monograph of the Pyrenulaceae (excluding Anthracothecium and Pyrenula) and the Requinellaceae, with notes on the Pleomassariaceae, the Trypetheliaceae and Mycomicrothelia (lichenized and non-lichenized Ascomycetes). Bibl. Lichenol. 1991, 44, $1-178$.

12. Maharachchikumbura, S.S.N.; Hyde, K.D.; Jones, E.B.G.; McKenzie, E.H.C.; Huang, S.K.; Abdel-Wahab, M.A.; Daranagama, D.A.; Dayarathne, M.; D'souza, M.J.; Goonasekara, I.D.; et al. Towards a natural classification and backbone tree for Sordariomycetes. Fungal Divers. 2015, 72, 199-301. [CrossRef]

13. Maharachchikumbura, S.S.N.; Hyde, K.D.; Jones, E.B.G.; McKenzie, E.H.C.; Bhat, J.D.; Dayarathne, M.C.; Huang, S.K.; Norphanphoun, C.; Senanayake, I.C.; Perera, R.H.; et al. Families of Sordariomycetes. Fungal Divers. 2016, 79, 1-317. [CrossRef]

14. Wijayawardene, N.N.; Hyde, K.D.; Rajeshkumar, K.C.; Hawksworth, D.L.; Madrid, H.; Kirk, P.M.; Braun, U.; Singh, R.V.; Crous, P.W.; Kukwa, M.; et al. Notes for genera: Ascomycota. Fungal Divers. 2017, 86, 1-594. [CrossRef]

15. Hongsanan, S.; Hyde, K.D.; Phookamsak, R.; Wanasinghe, D.N.; McKenzie, E.H.C.; Sarma, V.V.; Boonmee, S.; Lücking, R.; Bhat, D.J.; Liu, N.G.; et al. Refined families of Dothideomycetes: Dothideomycetidae and Pleosporomycetidae. Mycosphere 2020, 11, 1553-2107. [CrossRef]

16. Saccardo, P. Conspectus generum pyrenomycetum italicorum additis speciebus fungorum Venetorum novis vel criticis, systemate carpologico dispositorum. Atti Soc. Veneziana-Trent.-Istriana Sci. Nat. 1875, 4, 77-100.

17. Kang, J.C.; Hyde, K.D.; Kong, R.Y.C. Studies on Amphisphaeriales: The genera excluded from the Amphisphaeriaceae, Cainiaceae and Clypeosphaeriaceae. Fungal Divers. 1999, 2, 135-151.

18. Norphanphoun, C.; Jeewon, R.; Mckenzie, E.H.C.; Wen, T.C.; Camporesi, E.; Hyde, K.D. Taxonomic Position of Melomastia italica sp. nov. and Phylogenetic Reappraisal of Dyfrolomycetales. Cryptogam. Mycol. 2017, 38, 507-525. [CrossRef]

19. Phukhamsakda, C.; McKenzie, E.H.C.; Phillips, A.J.L.; Gareth Jones, E.B.; Jayarama Bhat, D.; Stadler, M.; Bhunjun, C.S.; Wanasinghe, D.N.; Thongbai, B.; Camporesi, E.; et al. Microfungi associated with Clematis (Ranunculaceae) with an integrated approach to delimiting species boundaries. Fungal Divers. 2020, 102, 1-203. [CrossRef]

20. Pang, K.L.; Hyde, K.D.; Alias, S.A.; Suetrong, S.; Guo, S.Y.; Idid, R.; Jones, E.G. Dyfrolomycetaceae, a new family in the Dothideomycetes, Ascomycota. Cryptogam. Mycol. 2013, 34, 223-232. [CrossRef]

21. Hyde, K.D.; Jones, E.B.G.; Liu, J.K.; Ariyawansa, H.; Boehm, E.; Boonmee, S.; Braun, U.; Chomnunti, P.; Crous, P.W.; Dai, D.Q.; et al. Families of Dothideomycetes. Fungal Divers. 2013, 63, 1-313. [CrossRef]

22. Samarakoon, M.C.; Maharachchikumbura, S.S.N.; Liu, J.J.; Hyde, K.D.; Promputtha, I.; Stadler, M. Molecular Phylogeny and Morphology of Amphisphaeria (= Lepteutypa) (Amphisphaeriaceae). J. Fungi 2020, 6, 174. [CrossRef]

23. Liu, J.K.; Chomnunti, P.; Cai, L.; Phookamsak, R. Phylogeny and morphology of Neodeightonia palmicola sp. nov. from palms. Sydowia 2010, 62, 261-276.

24. Chomnunti, P.; Hongsanan, S.; Aguirre-Hudson, B.; Tian, Q.; Peršoh, D.; Dhami, M.K.; Alias, A.S.; Xu, J.; Liu, X.; Stadler, M.; et al. The sooty moulds. Fungal Divers. 2014, 66, 1-36. [CrossRef]

25. Vilgalys, R.; Hester, M. Rapid genetic identification and mapping of enzymatically amplified ribosomal DNA from several Cryptococcus species. J. Bacteriol. 1990, 172, 4238-4246. [CrossRef]

26. White, T.J.; Bruns, T.; Lee, S.; Taylor, J.W. Amplification and direct sequencing of fungal ribosomal RNA genes for phylogenetics. In PCR Protocols: A Guide to Methods and Applications; Innis, M.A., Gelfand, D.H., Sninsky, J.J., White, T.J., Eds.; Academic Press: New York, NY, USA, 1990. 
27. Rehner, S. Primers for Elongation Factor 1-a (EF1-a). Available online: http://ocid.nacse.org/research/deephyphae/EF1primer. pdf (accessed on 25 November 2021).

28. Zhang, J.F.; Liu, J.K.; Hyde, K.D.; Chen, Y.Y.; Liu, X.Z.; Liu, Z.Y. Two new species of Dyfrolomyces (Dyfrolomycetaceae, Dothideomycetes) from karst landforms. Phytotaxa 2017, 313, 267-277. [CrossRef]

29. Senwanna, C.; Hongsanan, S.; Phookamsak, R.; Tibpromma, S.; Cheewangkoon, R.; Hyde, K.D. Muyocopron heveae sp. nov. and M. dipterocarpi appears to have host-jumped to rubber. Mycol. Prog. 2019, 18, 741-752. [CrossRef]

30. Hall, T.A. BioEdit: A User-Friendly Biological Sequence Alignment Editor and Analysis Program for Windows 95/98/NT. Nucleic Acids Symp. Ser. 1999, 41, 95-98.

31. Katoh, K.; Standley, D.M. MAFFT multiple sequence alignment software version 7: Improvements in performance and usability. Mol. Biol. Evol. 2013, 30, 772-780. [CrossRef]

32. Nylander, J.A. MrModeltest v2, Program Distributed by the Author, Evolutionary Biology Centre; Uppsala University: Uppsala, Sweden, 2004.

33. Dissanayake, A.J.; Bhunjun, C.S.; Maharachchikumbura, S.S.N.; Liu, J.K. Applied aspects of methods to infer phylogenetic relationships amongst fungi. Mycosphere 2020, 11, 2653-2677. [CrossRef]

34. Silvestro, D.; Michalak, I. raxmlGUI: A graphical front-end for RAxML. Org. Divers. Evol. 2012, 12, 335-337. [CrossRef]

35. Swofford, D.L. PAUP*. Phylogenetic Analysis Using Parsimony (And Other Methods). Version 4; Sinauer Associates: Sunderland, MA, USA, 2002.

36. Ronquist, F.; Teslenko, M.; Van Der Mark, P.; Ayres, D.L.; Darling, A.; Höhna, S.; Larget, B.; Liu, L.; Suchard, M.A.; Huelsenbeck, J.P. MrBayes 3.2: Efficient Bayesian phylogenetic inference and model choice across a large model space. Syst. Biol. 2012, 61, 539-542. [CrossRef]

37. Jayasiri, S.C.; Hyde, K.D.; Ariyawansa, H.A.; Bhat, J.; Buyck, B.; Cai, L.; Dai, Y.C.; Abd-Elsalam, K.A.; Ertz, D.; Hidayat, I.; et al. The Faces of Fungi database: Fungal names linked with morphology, phylogeny and human impacts. Fungal Divers. 2015, 74, 3-18. [CrossRef]

38. Crous, P.W.; Gams, W.; Stalpers, J.A.; Robert, V.; Stegehuis, G. MycoBank: An online initiative to launch mycology into the 21st century. Stud. Mycol. 2004, 50, 19-22.

39. Rambaut, A. FigTree v1. 4.0. A Graphical Viewer of Phylogenetic Trees. 2012. Available online: http://tree.bio.ed.ac.uk/ software/figtree (accessed on 1 December 2021).

40. Stenroosa, S.; Laukka, T.; Huhtinen, S.; Döbbeler, P.; Myllys, L.; Syrjänen, K.; Hyvönen, J. Multiple origins of symbioses between ascomycetes and bryophytes suggested by a five-gene phylogeny. Cladistics 2010, 26, 281-300. [CrossRef] [PubMed]

41. Nelsen, M.P.; Lücking, R.; Mbatchou, J.S.; Andrew, C.J.; Spielmann, A.A.; Lumbsch, H.T. New insights into relationships of lichen-forming Dothideomycetes. Fungal Divers. 2011, 51, 155-162. [CrossRef]

42. Mapook, A.; Hyde, K.D.; McKenzie, E.H.C.; Jones, E.B.G.; Bhat, D.J.; Jeewon, R.; Stadler, M.; Samarakoon, M.C.; Malaithong, M.; Tanunchai, B.; et al. Taxonomic and phylogenetic contributions to fungi associated with the invasive weed Chromolaena odorata (Siam weed). Fungal Divers. 2020, 101, 1-175. [CrossRef]

43. Dayarathne, M.C.; Jones, E.B.G.; Maharachchikumbura, S.S.N.; Devadatha, B.; Sarma, V.V.; Khongphinitbunjong, K.; Chomnunti, P.; Hyde, K.D. Morpho-molecular characterization of microfungi associated with marine based habitats. Mycosphere 2020, 11, 1-188. [CrossRef]

44. Hyde, K.D.; Norphanphoun, C.; Abreu, V.P.; Bazzicalupo, A.; Thilini Chethana, K.W.; Clericuzio, M.; Dayarathne, M.C.; Dissanayake, A.J.; Ekanayaka, A.H.; He, M.Q.; et al. Fungal diversity notes 603-708: Taxonomic and phylogenetic notes on genera and species. Fungal Divers. 2017, 87, 1-235. [CrossRef]

45. Hyde, K.D.; Chaiwan, N.; Norphanphoun, C.; Boonmee, S.; Camporesi, E.; Chethana, K.W.T.; Dayarathne, M.C.; de Silva, N.I.; Dissanayake, A.J.; Ekanayaka, A.H.; et al. Mycosphere notes 169-224. Mycosphere 2018, 9, 271-430. [CrossRef]

46. Hyde, K.D.; Hongsanan, S.; Jeewon, R.; Bhat, D.J.; McKenzie, E.H.C.; Jones, E.B.G.; Phookamsak, R.; Ariyawansa, H.A.; Boonmee, S.; Zhao, Q.; et al. Fungal diversity notes 367-490: Taxonomic and phylogenetic contributions to fungal taxa. Fungal Divers. 2016, 80, 1-270. [CrossRef]

47. Mapook, A.; Hyde, K.D.; Dai, D.Q.; Li, J.; Jones, E.B.G.; Bahkali, A.H.; Boonmee, S. Muyocopronales, ord. nov., (Dothideomycetes, Ascomycota) and a reappraisal of Muyocopron species from northern Thailand. Phytotaxa 2016, 265, 225-237. [CrossRef]

48. Tibpromma, S.; McKenzie, E.H.C.; Karunarathna, S.C.; Mortimer, P.E.; Xu, J.; Hyde, K.D.; Hu, D.M. Muyocopron garethjonesii sp. nov. (Muyocopronales, Dothideomycetes) on Pandanus sp. Mycosphere 2016, 7, 1480-1489. [CrossRef]

49. Mapook, A.; Hyde, K.D.; Hongsanan, S.; Phukhamsakda, C.; Li, J.F.; Boonmee, S. Palawaniaceae fam. nov., a new family (Dothideomycetes, Ascomycota) to accommodate Palawania species and their evolutionary time estimates. Mycosphere 2016, 7 , 1732-1745. [CrossRef]

50. Voglmayr, H.; Gardiennet, A.; Jaklitsch, W.M. Asterodiscus and Stigmatodiscus, two new apothecial dothideomycete genera and the new order Stigmatodiscales. Fungal Divers. 2016, 80, 271-284. [CrossRef]

51. Voglmayr, H.; Amengual, A.P. Three new species of Stigmatodiscus from Mallorca (Spain). Mycol. Prog. 2018, 17, 1189-1201. [CrossRef]

52. Voglmayr, H.; Fournier, J.; Jaklitsch, W.M. Stigmatodiscus pruni, a new dothideomycete with hysteriform ascomata. Sydowia 2017, 69, 29-35. [CrossRef] 
53. Van Nieuwenhuijzen, E.J.; Miadlikowska, J.M.; Houbraken, J.A.; Adan, O.C.; Lutzoni, F.M.; Samson, R.A. Wood staining fungi revealed taxonomic novelties in Pezizomycotina: New order Superstratomycetales and new species Cyanodermella oleoligni. Stud. Mycol. 2016, 85, 107-124. [CrossRef]

54. Schröter, J. Die Pilze Schlesiens. J. U. Kern. 1894, 2, 1889-1908.

55. Chen, C.Y.; Hsieh, W.H. Two new species and some new records of ascomycetes from Taiwan. Bot. Bull. Acad. Sin. 1996, 37, 219-227.

56. Thambugala, K.M.; Hyde, K.D.; Tanaka, K.; Tian, Q.; Wanasinghe, D.N.; Ariyawansa, H.A.; Jayasiri, S.C.; Boonmee, S.; Camporesi, E.; Hashimoto, A.; et al. Towards a natural classification and backbone tree for Lophiostomataceae, Floricolaceae, and Amorosiaceae fam. nov. Fungal Divers. 2015, 74, 199-266. [CrossRef]

57. Hashimoto, A.; Hirayama, K.; Takahashi, H.; Matsumura, M.; Okada, G.; Chen, C.Y.; Huang, J.W.; Kakishima, M.; Ono, T.; Tanaka, K. Resolving the Lophiostoma bipolare complex: Generic delimitations within Lophiostomataceae. Stud. Mycol. 2018, 90, 161-189. [CrossRef] 